\title{
Creeping Bluestem Response to Prescribed Burning and Grazing in South Florida
}

\author{
LARRY D. WHITE AND W. STEVE TERRY
}

\begin{abstract}
Many research studies have developed guidelines for managing wiregrass ranges to improve utilization of relatively unpalatable Aristida and Sporobolus spp. This traditional management has generally produced low livestock returns. Recent management trends have been toward the promotion and utilization of more desirable bluestems, paspalums, panicums, etc. This study was initiated to determine how wiregrass management affects excellent creeping bluestem pastures. Results indicate that prescribed burning stimulated reproductive culm development at the expense of foliage production. Grazing of burned areas with dominance of reproductive culms resulted in a substantial decrease in creeping bluestem tiller survival and herbage production. Continuous grazing of burned areas allows the more grazing resistant wiregrasses and shrubs to increase and probably accounts for the present expanse of wiregrass ranges. Deferment of grazing until seedset of desirable grasses following late winter burning would promote the development of productive bluestem pastures. Prescribed burning is a recommended practice to be continued for south Florida; however, it should occur after cattle have been removed from the pasture. A rotation system with fire every 3 to 5 years is suggested to improve ranges from wiregrass to bluestem dominance and to maintain creeping bluestem pastures.
\end{abstract}

The current financial crisis of many ranchers has greatly emphasized the value of range forage for cow-calf herds in Florida. Many Florida cattlemen continue to utilize range as winter roughage following prescribed burning. Research has demonstrated that burning improves nutritive value of wiregrasses (Aristida and Sporobolus spp.) for 2 to 3 months after a fire (Hughes 1970; Hilmon and Hughes 1965; Halls et al. 1957) while unburned areas are grazed free-choice by cattle only after close utilization of recent burns. After wiregrasses reach maturity, within 4 to 6 months after a fire, cattle prefer to graze the more palatable warm-season grasses year-long (Hughes 1970), ie., panicums, bluestems, paspalums, etc. Hughes recommended heavy use of pineland threeawn (Aristida stricta), the predominant wiregrass in south Florida, after winter burning and deferment of grazing during the late spring and summer to encourage the better grasses. Yarlett (1963) concluded that the process of repeated burning and uncontrolled grazing on fresh burns decreased desirable forage species such as creeping bluestem (Schizachyrium stolonifer) and created the present wiregrass ranges.

The athors are range extension specialist. Texas A\&M University. Uvalde, and research biologist, School of Forest Resources and Conservation, University of Florida. Gainesville, respectively. At the time of the study the senior author was associate professor, School of Forest Resources and Conservation. University of Florida. Gainesville:

Manuscript received February 3, 1978.
This paper describes the leaf area, basal area. tiller density and herbage production response of creeping bluestem on burned and unburned grazed flatwoods range in south Florida. Florida.

\section{Study Area and Methods}

The study was conducted on the Agricultural Research Center at Ona, Florida. Grazed and ungrazed range pastures dominated by creeping bluestem on Myakka-Immokalee fine sand soils were prescribe burned after 10 years of protection from fire. Paired plants were sampled for leaf area index (LAI), basal area, tiller density, and biomass of leaves and culms of creeping bluestem.

Two 16-ha lightly grazed pastures, one unburned and one burned March 1974, were sampled in September 1974 and October 1975. Forty 10-pin point frames were utilized to sample for vegetative cover on both areas in September 1974. Twenty point frames were used thereafter, since graphical analysis indicated this number to be sufficient to obtain results within $5 \%$ of the mean (based on 40 quadrats) (Kershaw 1964).

One 4-hectare ungrazed pasture was sampled in September 1974. burned in January 1975, and resampled in October 1975. Twenty systematically located point frames per pasture were used for sampling hefore and after burning. In October 1975, ten systematically located square $0.25 \mathrm{~m}^{2}$ quadrats were clipped from each of the pastures plus an ungrazed unburned area adjacent to the 4 hectare pasture. Clipped biomass was sorted to dead and live (with live further sorted to creeping bluestem vegetative material and culms and other plants). Dry weight was determined after oven-drying at $65^{\circ} \mathrm{C}$ for a minimum of 48 hours. Tiller counts of creeping bluestem were made on each clip quadrat prior to harvest. A paired $t$ test at the $95 \%$ level of probability was used to test differences between treatments.

\section{Results}

Total leaf area index (LAI) on a south Florida flatwoods range significantly decreased from 1974 to 1975 on grazed unburned and grazed burned pastures (Table 1). The highest LAI (0.668) was measured in 1974 on the grazed unburned pasture which was similar to that on the grazed burned pasture. Also, one growing season after burning, the ungrazed pasture did not significantly change in LAI compared to measurements $(0.468)$ on the same area prior to the March burn. The second growing season total LAI on the burned grazed pasture had significantly decreased below the LAI on the grazed unburned pasture.

Species responded differently to the grazing and burning treatments (Table 1). Creeping bluestem had significantly higher LAI on unburned and grazed pastures compared to burned and grazed pastures both growing seasons. A significant decrease in LAI resulted only on the grazed pasture one growing 
Table 1. Leaf area index (LAI) at the end of the growing season on south Florida flatwoods range as affected by burning and cattle grazing.

\begin{tabular}{|c|c|c|c|c|c|c|}
\hline \multirow[b]{4}{*}{ Plant category } & \multirow{2}{*}{\multicolumn{2}{|c|}{$\begin{array}{l}\text { Not grazed } \\
\text { Pasture } 1\end{array}$}} & \multicolumn{4}{|c|}{ Grazed } \\
\hline & & & \multirow{2}{*}{\multicolumn{2}{|c|}{$\begin{array}{l}\text { Pasture 2 } \\
\text { Not burned }\end{array}$}} & \multirow{2}{*}{\multicolumn{2}{|c|}{$\begin{array}{c}\text { Pasture } 3 \\
\text { Burned March } 1974\end{array}$}} \\
\hline & \multirow{2}{*}{$\begin{array}{c}\text { Prior to burn } \\
\text { (1974) }\end{array}$} & \multirow{2}{*}{$\frac{\text { Burned January } 1975}{(1975)}$} & & & & \\
\hline & & & (1974 & (1975) & (1974) & (1975) \\
\hline Creeping bluestem & $0.200^{a b 1}$ & $0.145^{b c d}$ & $0.323^{a b}$ & $0.325^{a}$ & $0.070^{r}$ & $0.023^{d}$ \\
\hline Other grasses & $0.045^{b}$ & $0.020^{b}$ & $0.155^{a}$ & $0.033^{b}$ & $0.088^{a b}$ & $0.088^{a t b}$ \\
\hline Grasslike plants & $0.000^{a}$ & $0.030^{a b}$ & $0.005^{a}$ & $0.000^{r}$ & $0.058^{b}$ & $0.003^{\prime \prime}$ \\
\hline Forbs & $0.035^{a b}$ & $0.020^{a b}$ & $0.033^{a b}$ & $0.013^{n}$ & $0.060^{t}$ & $0.020^{a t}$ \\
\hline Shrubs & $0.005^{a}$ & $0.045^{a}$ & $0.153^{b}$ & $(0.1 ! 1)^{n+s}$ & $0.223^{\prime \prime}$ & $0.043^{\prime \prime}$ \\
\hline Total & $0.285^{b c}$ & $0.260^{b c}$ & $0.668^{a}$ & $0.4 \times 0^{h}$ & $0.498^{a t}$ & $0.173^{r}$ \\
\hline
\end{tabular}

season after burning. The LAI on the grazed and burned pasture continued to decrease (significantly) the second growing season, 1974 to 1975 .

The percent basal area of creeping bluestem was significantly higher $(16.5 \%)$ on the grazed unburned pasture in 1974 as compared to the ungrazed unburned $(6.0 \%)$ and grazed burned pastures $(1.8 \%)$. In 1975 , there was a significant difference between the grazed unburned $(11.8 \%)$ pasture and the ungrazed burned $(2.5 \%)$ and grazed burned $(3.5 \%)$ pastures.

Other grasses had a significantly lower LAI prior to burning on pasture l compared to the grazed unburned pasture (Table 1). However, both pastures were similar in 1975 even after burning pasture 1. The grazed burned pasture maintained a similar LAI both growing seasons after the fire and was not significantly different from the grazed unburned pasture. Grasslike plants (sedges and rushes) were not frequently encountered on the pastures; however, the highest LAI occurred on the grazed burned pasture the first growing season after burning. The highest total forb LAI occurred on the grazed burned area the first growing season. Generally, forbs were not significantly affected by season, grazing. or burning treatments. The LAI of all shrubs combined was significantly higher on grazed pastures compared to the ungrazed pasture especially one growing season after burning.

The total tiller density of creeping bluestem on the ungrazed and burned pasture was significantly different from density on the other pastures (Table 2). The lowest tiller density occurred on the burned and grazed pasture two growing seasons after the fire. On the ungrazed pasture, burning resulted in a significant increase in reproductive tillers. Stimulation in flowering by burning was evident the first growing season after burning (Fig. 2). However. within two growing seasons after burning (March 1974 burn) followed by cattle grazing, the density of tillers was similar to density on the unburned grazed pasture. The lowest vegetative tiller density on the grazed and burned pasture was significantly lower than that of the ungrazed and unburned

Table 2. Creeping bluestem tiller density $\left(\right.$ no. $\left./ \mathrm{m}^{2}\right)$ in October 1975 on south Florida flatwoods range as affected by burning and cattle grazing.

\begin{tabular}{|c|c|c|c|c|}
\hline \multirow[b]{2}{*}{ Tiller type } & \multicolumn{2}{|c|}{ Not grazed } & \multicolumn{2}{|c|}{ Grazed } \\
\hline & Not burned & $\begin{array}{c}\text { Burned } \\
\text { January } 1975\end{array}$ & Not burned & $\begin{array}{c}\text { Burned } \\
\text { March } 1974\end{array}$ \\
\hline $\begin{array}{l}\text { Reproductive } \\
\text { (R) }\end{array}$ & $4.0^{\prime \prime 1}$ & $75.8^{b}$ & $1.0^{n}$ & $1.6^{\prime \prime}$ \\
\hline (V) & $82.2^{\prime \prime}$ & $52.0^{t}$ & $49 \cdot 2^{n h b}$ & $28.4^{b}$ \\
\hline $\begin{array}{l}\mathrm{R} \backslash \text { ratio } \\
\text { Total tillers }\end{array}$ & $\begin{array}{l}0.05 \\
87.2 \text { ath }\end{array}$ & $\begin{array}{r}1.46 \\
127.8^{b}\end{array}$ & $\begin{array}{l}0.02 \\
50.2 a r\end{array}$ & $\begin{array}{l}0.06 \\
30.0 \%\end{array}$ \\
\hline
\end{tabular}

Mcam followed by the same letler w ithin tiller ty pe do not difler significantly at the 5 , lici pasture. The ratio of reproductive to vegetative tillers further illustrates the first growing season effects of burning.

Total herbage biomass at the end of the 1975 growing season was significantly higher on the ungrazed unburned pasture due to dead standing crop as compared to the other treatments (Table 3). Total biomass was significantly lower on the grazed burned pasture two growing seasons after the fire than on the other areas.

Creeping bluestem biomass distribution among leaves (L) and culms (C) further substantiated the significant shift from vegetative to reproductive material the first growing season after burning (Table 3 ). The $\mathrm{C} / \mathrm{L}$ ration on the ungrazed burned area fully illustrates the potential reproductive to vegetative emphasis the first year after burning. Two years after burning followed by cattle grazing still resulted in a higher $\mathrm{C} / \mathrm{L}$ ratio than on the ungrazed unburned or grazed unburned areas, although this later ratio was substantially less than first year grazed burning results. Total biomass of creeping bluestem tillers was significantly lower on the grazed pasture, especially two growing seasons after the fire.

The first growing season after the fire on the ungrazed area there was not a significant difference in total tiller biomass; however, there was a significant shift from vegetative to reproductive tiller biomass with a decrease in leaf tissue development. On the grazed areas culm biomass was similar between burned and unburned areas; however, leaf biomass was substantially (significantly) lower on the grazed and burned areas.

\section{Discussion and Conclusions}

All measurements indicate a physiological shift in carbohy-

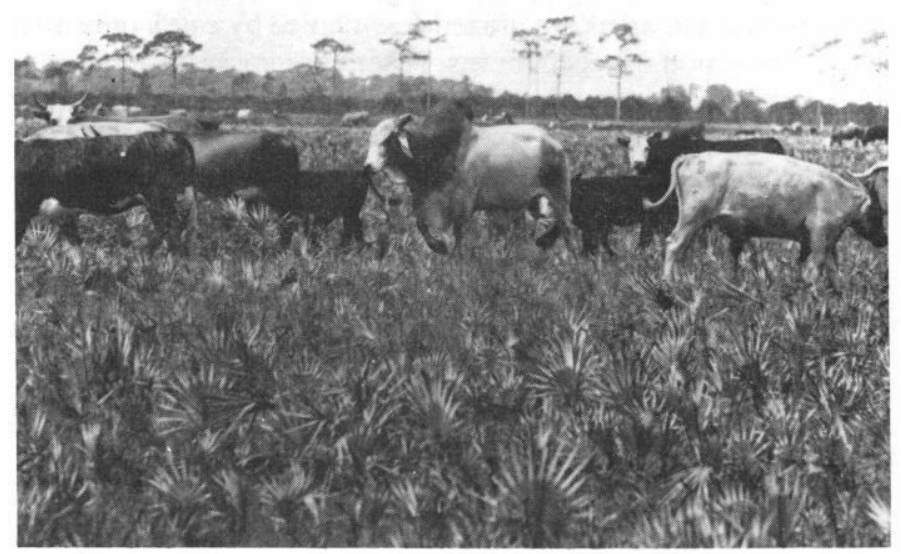

Fig. 1. South Florida wiregrass range under traditional management, i.e. winter burning followed by continuous cattle grazing. Note the dominance of saw-palmetto and pineland threeawn. 
Table 3. Herbage production (kg/ha) in October 1975 on south Florida flatwoods range as affected by burning and cattle grazing.

\begin{tabular}{|c|c|c|c|c|c|}
\hline \multirow[b]{2}{*}{ Plant category } & \multirow[b]{2}{*}{ Plant component } & \multicolumn{2}{|c|}{ Not grazed } & \multicolumn{2}{|c|}{ Grazed } \\
\hline & & Not burned & Burned January 1975 & Not burned & Burned March 1974 \\
\hline Creeping bluestem & culms (C) & $316.0^{a 1}$ & $2372.0^{b}$ & $48.0^{a}$ & $40.0^{a}$ \\
\hline & leaves $(\mathrm{L})$ & $2864.0^{a}$ & $996.0^{b}$ & $1056.0^{b}$ & $184.0^{c}$ \\
\hline Creeping bluestem & Total & $3180.0^{a}$ & $3368.0^{a}$ & $1104.0^{b}$ & $224.0^{c}$ \\
\hline Creepıng bluestm & C/L Ratio & 0.11 & 2.38 & 0.05 & 0.22 \\
\hline Other plants & Total & $308.0^{a}$ & $836.0^{a b}$ & $980.0^{b}$ & $1992.0^{c}$ \\
\hline Dead & Total & $5204.0^{a}$ & $744.0^{c}$ & $2696.0^{b}$ & $384.0^{c}$ \\
\hline Live Biomass & Total & $3488.0^{a}$ & $4204.0^{a}$ & $2084.0^{b}$ & $2216.0^{b}$ \\
\hline Biomass & Total & $8692.0^{a}$ & $4948.0^{b}$ & $4780.0^{b}$ & $2600.0^{c}$ \\
\hline
\end{tabular}

drate energies from vegetative leaf biomass dominance in ungrazed and unburned pastures to that of massive reproductive development the first year after a fire. These results support the findings of other researchers on the effects of fire on bluestems and southeastern range species in general (Daubenmire 1968). Hilmon and Hughes (1965) concluded that the value of fire in the wiregrass type had been demonstrated. "Fire improves quality and productivity of wiregrass forage, aiding distribution of cattle, stimulating native grasses to produce seed, and checking growth of undesirable shrubs." Yarlett (1970) reported the normal reproductive to vegetative tiller ratio for creeping bluestem as 1:5 on unburned ungrazed south Florida range. The ratios observed in this study following burning approximate the 2:1 described by Branson (1953), a condition in grasses he considered to be intolerant to grazing. The results indicate the grazing of burned areas greatly decreased vegetative biomass. Therefore grazing of fresh burns apparently
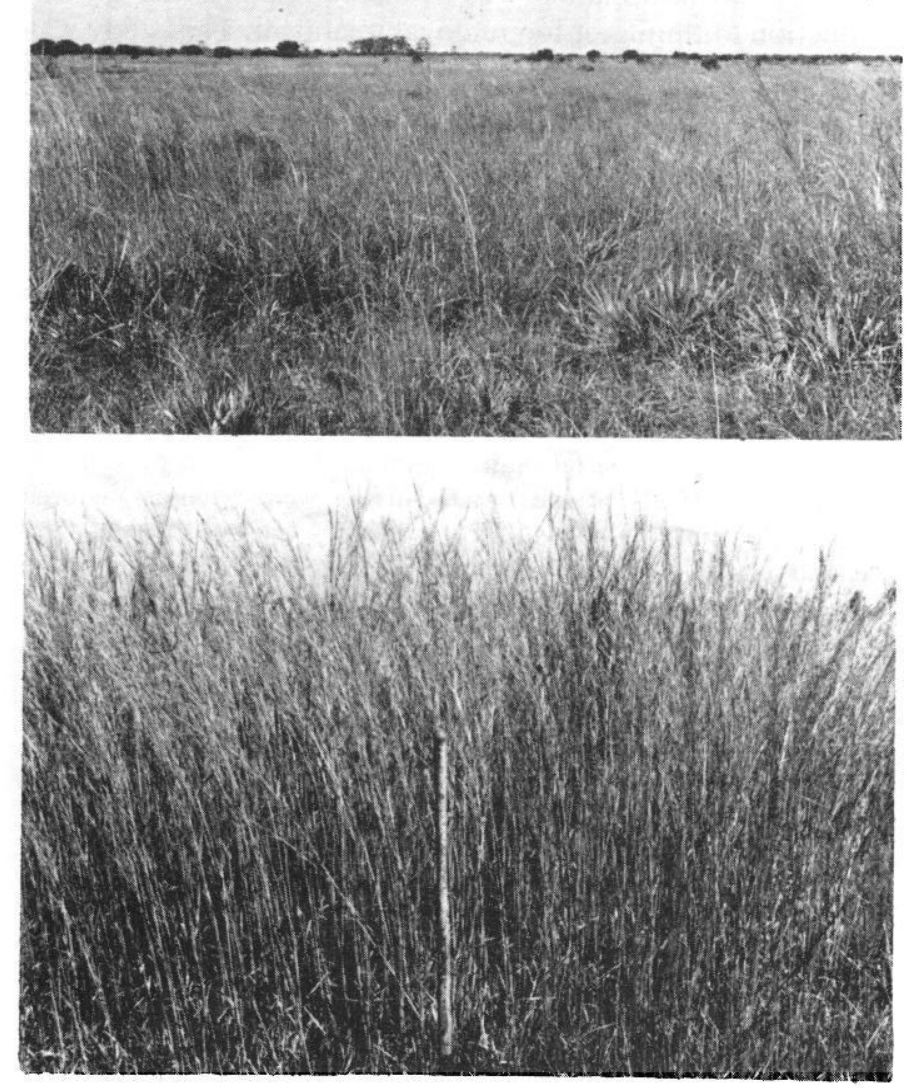

Fig. 2. An excellent creeping bluestem, saw-palmetto range in south Florida 5 years after chopping and 10 years of fire exclusion. Note the dominance of creeping bluestem vegetative tillers prior to burning (top) and primarily reproductive tillers I year after burning on the same area (bottom). results in considerable herbage intake of tillers that have been stimulated to form reproductive culms. Most range literature clearly illustrates that heavy grazing of plants during development of reproductive culms results in the most damage to the plants.

In conclusion, these results and understanding of past range burning and grazing practices would appear to explain Yarlett's (1963) conclusion as to the development of ranges dominated by wiregrasses rather than bluestem. Principal causes for this change in species dominance on burned and grazed pastures are continued grazing preference for bluestem following a fire, little preference for wiregrasses after 3-4 months following the burn, and the probable physiological conditions of bluestem tillers (reproductive emphasis over vegetative development) which would greatly increase bluestem susceptibility to grazing. Hilmon and Hughes (1965) reported that "wiregrass" adaptation to sprout quickly after the fire coupled with early decline in quality and palatability operate to maintain or increase the abundance of wiregrasses in the type. Hence results indicate the management for creeping bluestem will require deferment of grazing until seed-set following a fire if maximum tiller survival and herbage production are desired. This type of management recommended by Yarlett and Roush (1970) should allow the development of highly productive south Florida ranges dominated by creeping bluestem rather than the less desirable wiregrasses and shrubs. This type of program is contrary to that of Duvall and Hilmon (1965) where "deferred grazing and deferred rotation grazing" were considered unsuccessful in the South on wiregrass dominated ranges. The apparent reasons for failure of the rotation type system compared to the burn-rotation system as suggested here was their objective in managing wiregrass rather than bluestem.

\section{Literature Cited}

Branson, F.A. 1953. Two new factors affecting resistance of grasses to grazing. J. Range Manage. 6:165-171.

Daubenrinire, R. 1968. Ecology of fire in grasslands. In: Cragg, J. B. Advances in Ecological Research, Academic Press, N.Y. 5:209-266.

Duvall, V.L., and J.B. Hilmon. 1965. New grazing research programs for southern forest ranges. J. Range Manage. 18:132-136.

Halls, L.K., O.M. Hale, and F.E. Knox. 1975. Seasonal variation in grazing use, nutritive content, and digestibility of wiregrass forage. Georgia Agr. Exp. Sta. Tech. Bull. N.S. 11. 28 p.

Hilmon, J.B., and R.H. Hughes. 1965. Fire and forage in the wiregrass type. J. Range Manage. 18:251-254.

Hughes, R.H. 1970. Year-long management of forage and cattle on pinewiregrass ranges of the southeastern United States. Int. Grassl. Cong. Proc. 11:45-48.

Kershaw, K.A. 1964. Quantitative and Dynamic Ecology. American Elsevier Publ. Co., New York.

Yarlett, L.L. 1963. Some important and associated native grasses on central and south Florida ranges. J. Range Manage. 16:25-27.

Yarlett, L.L., and R.D. Roush. 1970. Creeping bluestem (Andropogon stolonifer (nash) Hitch). J. Range Manage. 23:117-122. 